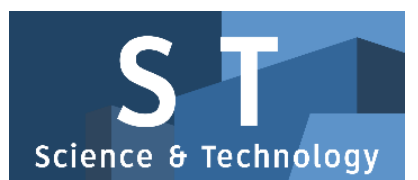

PAPER - OPEN ACCESS

\title{
Perbandingan Keakuratan Dari Model Tabel Distribusi Frekuensi Berkelompok Antara Metode Sturges Dan Metode Scott
}
Author
: Wanda Maya Sari
DOI
: 10.32734/st.v1i1.182
Electronic ISSN
: 2654-7094
Print ISSN
: 2654-7086

Volume 1 Issue 1 - 2018 TALENTA Conference Series: Science \& Technology (ST)

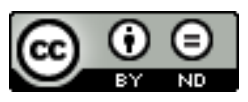

This work is licensed under a Creative Commons Attribution-NoDerivatives 4.0 International License.

Published under licence by TALENTA Publisher, Universitas Sumatera Utara
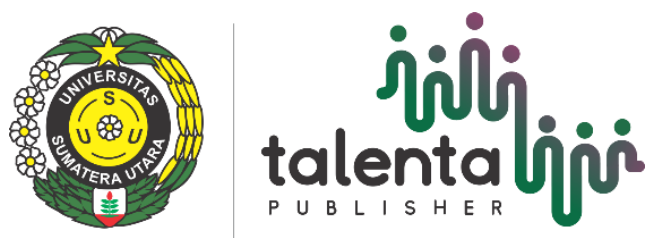


\title{
jijili talentalioำ TALENTA Conference Series \\ P U B L I S H E R Available online at https://talentaconfseries.usu.ac.id \\ Perbandingan Keakuratan dari Model Tabel Distribusi Frekuensi Berkelompok Antara Metode Sturges dan Metode Scott
}

\author{
Wanda Maya Sari ${ }^{\mathrm{a}}$, Open Darnius ${ }^{\mathrm{a}}$, dan Pasukat Sembiring ${ }^{\mathrm{a}}$ \\ Fakultas Matematika dan Ilmu Pengetahuan Alam, Universitas Sumatera Utara, Medan 20155, Indonesia \\ wandamayasari1@gmail.com
}

\begin{abstract}
Abstrak
Distribusi Frekuensi berkelompok adalah penyusunan urutan data tunggal ke dalam tabel kelas-kelas interval, untuk kemudian ditentukan frekuensinya. Penyusunan ini berguna untuk menyelidiki kumpulan data sehingga dapat membawa informasi dengan cara yang pintas. Metode Sturges adalah aturan yang paling dikenal untuk menentukan jumlah kelas interval dalam distribusi frekuensi, namun terdapat kelemahan di dalamnya sehingga pada penelitian ini dilakukan analisis perbandingan keakuratan model tabulasi antara Metode Sturges dengan Metode Scott yang merupakan aturan untuk menentukan panjang kelas dalam distribusi frekuensi. Perbandingan dilihat dari hasil perhitungan selisih ukuran pemusatan, ukuran lokasi, serta dispersiantara kedua model terhadap ukuran dari data simulasinya (data aktual), kemudian dianalisis perbandingannya melalui jenis distribusi data, yang dalam penelitian ini menggunakan data berdistribusi normal dan eksponensial. Hasil perbandingan keakuratan dari masing- masing tabel distribusi frekuensi dari data normal maupun data eksponensial, menunjukkan persentasi keakuratan dari tabel distribusi frekuensi dengan metode scott lebih tinggi dibandingkan dengan metode sturges, hal ini dikarenakan, pada tabel distribusi frekuensi dengan metode sturges, terdapat data yang tidak masuk ke dalam tabel distribusi frekuensi diakibatkan nilai panjang kelas interval tidak dapat mencakup pengelompokkan sampai data tertinggi.
\end{abstract}

Kata Kunci: Distribusi Frekuensi Kelompok; Kelas Interval; Metode Sturges; Metode Scott; Data Simulasi.

\section{Pendahuluan}

Untuk menyajikan data kuantitatif menjadi bentuk yang baik dapat disusun dengan cara distribusi frekuensi berkelompok, di mana data yang sudah berkelompok dimasukkan ke dalam rentang ukuran yang sama atau dikenal dengan istilah kelas interval, yang biasa disimbolkan dengan $K$. Metode yang paling dikenal dalam menentukan banyak kelas interval $(K)$ adalah aturan yang dirancang oleh ${ }^{[1]}$. Salah satu kritikan oleh ${ }^{[2]}$ yaitu aturan sturges mengandung beberapa kelemahan, di mana untuk jumlah data $(n)$ yang terlampau besar akan memberikan hasil yang tidak baik. Adapun dalam jurnalnya, ${ }^{[3]}$ menyatakan bahwa rumus jumlah kelas interval sturges mempunyai kemungkinan dapat bertahan selama ini, karena untuk $n$ sedang (kurang dari 200) dapat memberikan hasil histogram yang layak. Hyndman mengajukan salah satu rumus dalam penentuan panjang kelas interval, yaitu aturan ${ }^{[4]}$ yang dipublikasikan dalam jurnalnya yang berjudul -On Optimal and Data-Based Histograms

\footnotetext{
${ }^{1}$ Sturges, H. (1926). The Choice of A Class Interval. Journal American Statistical Association. 21.65-66

${ }^{2}$ Dajan, A.nto. (1986). Pengantar Metode Statistik 2. LP3ES. Jakarta.

${ }^{3}$ Hyndman, Rob J. (1995). The Problem with Sturges's Rule for Constructing Histograms. A shortnotes. Unpublished Article.

${ }^{4}$ Scott, David W. (1979). On Optimal Data-Based Histograms. Biometrika Trust. 3.605-610

Jika dilakukan perhitungan nilai kriteria ukuran pemusatan, lokasi, dan dispersi pada data berkelompok dalam tabel distribusi frekuensi akan terjadi perbedaan perhitungan dengan data tunggalnya (sebelum dikelompokkan). Perbedaan
} 
demikian dikatakan sebagai selisih akibat pengelompokkan (grouping error) [2]. Melalui permasalahan tersebut, dalam penelitian ini dilakukan analisa perbandingan keakuratan dari model tabel distribusi frekuensi berkelompok antara penggunaan metode sturges dan metode scott terhadap nilai selisih pengelompokkan yang berdasarkan nilai kriteria rata-rata, median, kuartil 1, kuartil 3, standar deviasi, dan varians data.

\section{Tujuan}

Mengetahui perbandingan keakuratan model tabel distribusi frekuensi berkelompok yang dapat mendekati data aktual, yaitu antara model yang menggunakan metode sturges dan metode scott, sehingga selisih akibat pengelompokkan (grouping error) yang terjadi dalam tabel distribusi frekuensi semakin kecil.

\section{Metode}

Model tabel distribusi frekuensi yang diteliti dalam penelitian ini, diperoleh dari hasil program yang dirancang menggunakan bantuan software Matlab Guide, dan untuk membandingkan keakuratan model tabel distribusi frekuensi dilakukan dengan analisis perbandingan selisih hasil simulasi perhitungan ukuran pemusatan, lokasi, dan dispersi data menggunakan kode program yang dirancang dengan software Matlab Guide. Adapun data yang digunakan adalah data kontinu dari hasil data simulasi yang dibangkitkan melalui program R. Berikut tahapan analisis penelitian ini:

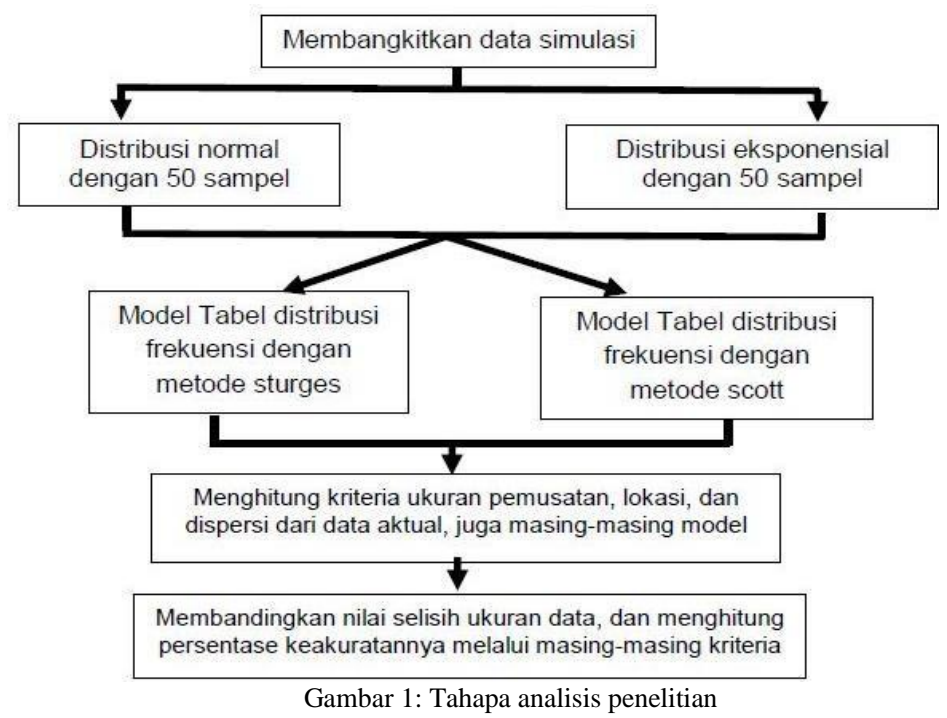

\section{Hasil Penelitian}

\subsection{Metode Sturges}

Metode sturges adalah aturan untuk menentukan seberapa luas dipilih data dalam suatu grafik batang pada histogram. Aturan ini dipublikasikan pada jurnal American Statistical Association (ASA) pada tahun 1926. Sturges menganggap jumlah data dalam sebuah interval adalah dari koefisien binomial, dan sturges mengasumsikan bahwa satu kumpulan data terdistribusi baik didekati dengan distribusi binomial dengan probabilitas 0,5 (memberikan distribusi simetris). Pada penurunan aturan tersebut digunakan identitas ekspansi binomial dan sifat logaritma, sehingga aturan sturges adalah

$$
K \approx 1+3,322 \log n
$$




\subsection{Metode Scott}

Metode scott adalah sebuah aturan yang memberikan sebuah pilihan dari nilai lebar (panjang) kelas dalam sebuah histogram dengan ukuran data kontinu. Dalam jurnal yang dipublikasikan Biometrika Trust, Aturan ini dideskripsikan berasal dari perhitungan ketidaksesuaian dalam integrasi rata-rata kesalahan kuadrat (Integrated Mean Squared Error) pada lebar kelas interval. Aturan tersebut didefinisikan sebagai berikut:

$$
p=3,4908 s n^{1 / 3}
$$

\subsection{Proses Pembangkitan Data Simulasi dan Perhitungan Ukuran Pemusatan Data, Lokasi, dan Dispersi Data}

Dalam penelitian ini, data simulasi yang dibangkitkan menggunakan program $\mathrm{R}$, dengan data berdistirbusi normal dan berdistribusi eksponensial. Dengan ukuran sampel dari 20, 25, 30, .., 265 data (50 data simulasi) dan dengan parameter rata-rata $(\mu)$ adalah 50 dan standar deviasi $(\sigma)$ adalah 5. Fungsi perintah untuk membangkitkan data simulasi berdistribusi normal adalah:

$$
\operatorname{rnorm}(n, \mu, \sigma)
$$

dan fungsi perintah untuk membangkitkan data eksponensial adalah:

$$
\operatorname{rexp}\left(n, \frac{1}{\mu}\right)
$$

Masing-masing hasil data simulasi dari program yang dijalankan, disimpan dalam variabel $X_{1}, X_{2,}, X_{3, \ldots}, X_{50}$ untuk data berdistribusi normal, dan variabel $Y_{1}, Y_{2}, Y_{3}, \ldots, Y_{50}$ untuk data berdistribusi eksponensial.Data tersebut merupakan data tunggal sehingga dalam penelitian ini diolah menjadi distribusi frekuensi berkelompok. Dari data tersebut dilakukan perhitungan kriteria ukuran pemusatan data yaitu rata-rata dan median, lalu ukuran lokasi yang dihitung adalah kuartil 1 dan kuartil 3, serta ukuran dispersi yang hitung adalah varians dan standar deviasi. Perhitungan dilakukan dengan merancang program dalam Matlab. Hasil perhitungan kriteria ukuran dari data simulasi pada variabel $X_{I}$ ditunjukkan pada Gambar 2, dan dilakukan perhitungan yang sama untuk semua data simulasi berdistribusi normal dan berdistribusi eksponensial.

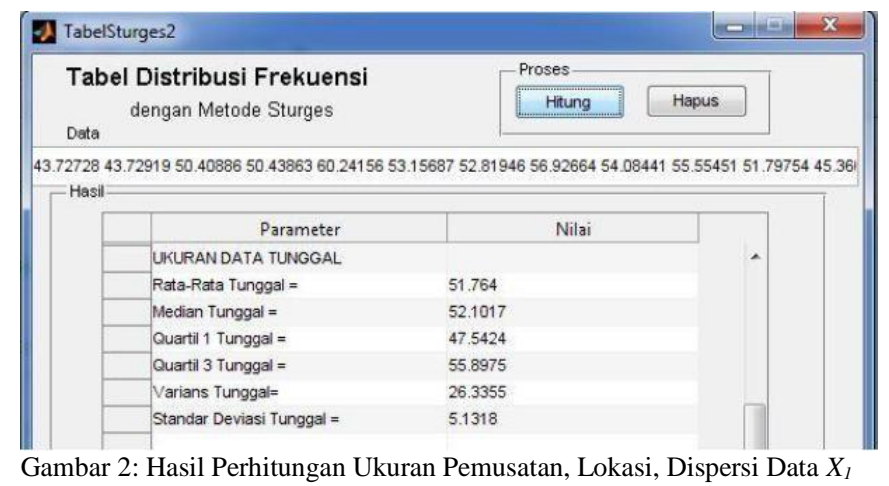

Untuk semua data simulasi dilakukan tabulasi menjadi tabel distribusi frekuensi, masing-masingnya dengan menggunakan metode sturges dan metode scott. Pembentukan tabel distribusi frekuensi tersebut didapatkan dari hasil program aplikasi yang dirancang pada Matlab. Hasil keluaran program untuk data tunggal pada sampel $X_{l}$ menjadi model tabel distribusi frekuensi dengan metode sturges, ditunjukkan pada Gambar 3. Untuk model dengan metode scott, ditunjukkan pada Gambar 4. 
Dari Gambar 3, terlihat bahwa model tabel distribusi frekuensi data normal dengan metode sturges tidak mencakup keseluruhan data, di mana hanya 19 data dari 20 data, sedangkan model menggunakan metode scott pada Gambar 4, dapat mencakup keseluruhan data. Untuk data eksponensial terlihat hal yang sama pula, yaitu pada model sturges, tabel distribusi frekuensi tidak mencakup keseluruhan data.

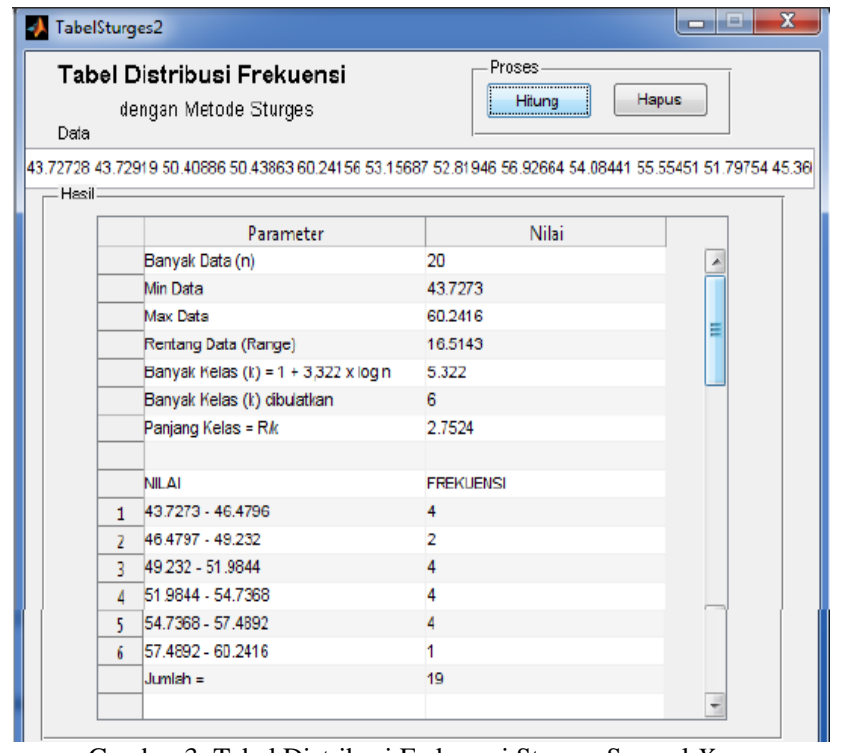

Gambar 3: Tabel Distribusi Frekuensi Sturges Sampel $X_{l}$

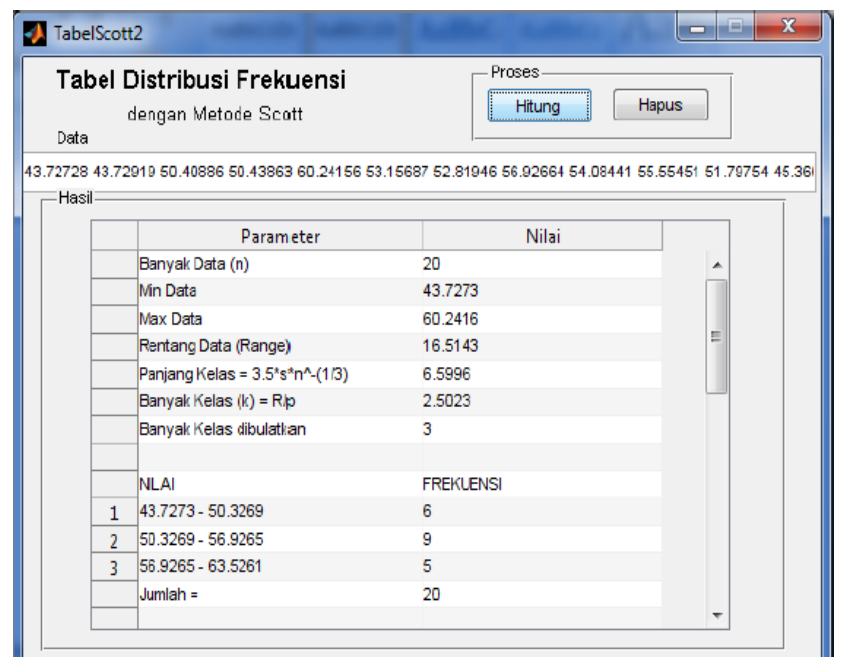

Gambar 4: Tabel Distribusi Frekuensi Scott Sampel $X_{I}$ 


\subsection{Perhitungan Ukuran Pemusatan, Lokasi, dan Dispersi Data pada Tabel Distribusi Frekuensi}

Masing-masing model tabel distribusi frekuensi dengan data normal dan eksponensial, dilakukan perhitungan kriteria ukuran data seperti pada data tunggalnya, yaitu rata-rata, median, kuartil 1, kuartil 3, varians, dan standar deviasi. Perhitungan dilakukan dengan merancang program pada Matlab. Hasil perhitungan kriteria ukuran data dari tabel distribusi frekuensi sturges pada sampel $X_{l}$ ditunjukkan pada Gambar 5.

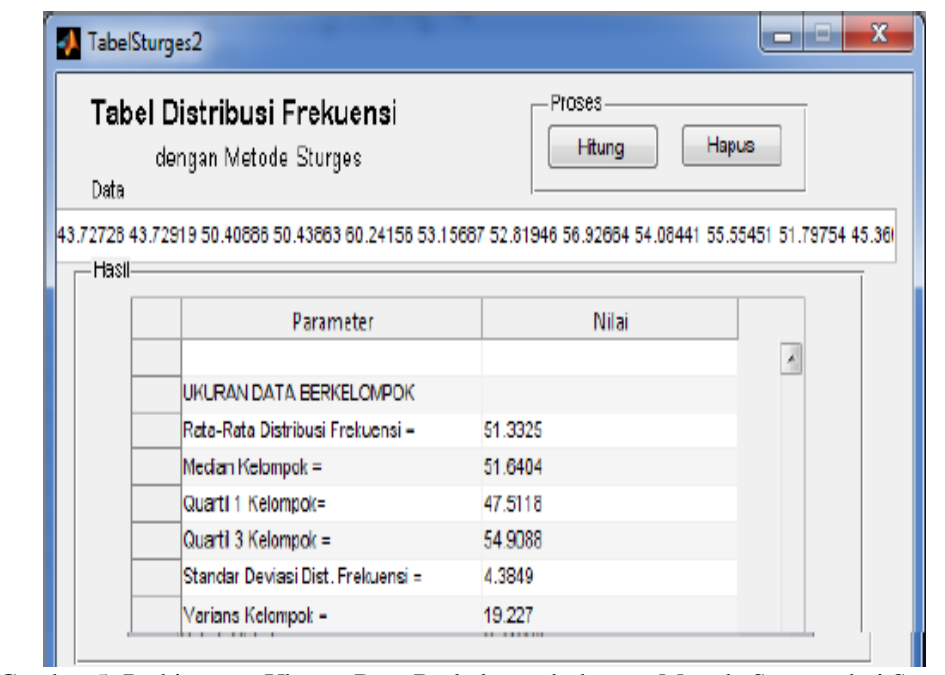

Gambar 5: Perhitungan Ukuran Data Berkelompok dengan Metode Sturges dari Sampel $X_{1}$

\subsection{Analisis Perbandingan Keakuratan Model Tabel Distribusi Frekuensi}

Perbandingan keakuratan didapatkan dengan membandingkan selisih kriteria ukuran data yang telah dihitung sebelumnya pada data tunggal dan data berkelompok dalam masing-masing tabel distribusi frekuensi. Untuk data berdistribusi normal, perbandingan selisih kriteria ukuran data pada masing- masing sampel data simulasi ditunjukkan pada Tabel 1, Tabel 2, dan Tabel 3.

Berdasarkan hasil perbandingan dalam 50 percobaan simulasi dengan ukuran sampel 20 sampai 265, Untuk data berdistribusi normal, model tabel distribusi frekuensi menggunakan metode scott lebih akurat dibandingkan dengan metode sturges, persentasi perbandingan hasil simulasi menunjukkan $58 \%$ nilai rata-rata, $58 \%$ nilai $\mathrm{Q}_{1}, 52 \%$ nilai $\mathrm{Q}_{3}$, $86 \%$ nilai varians dan $84 \%$ nilai standar deviasi lebih akurat ke metode scott. Hanya pada nilai median $58 \%$ lebih akurat menggunakan metode sturges dibandingkan metode scott.

Untuk data berdistribusi eksponensial, model tabel distribusi frekuensi menggunakan metode scott juga lebih akurat dibandingkan dengan metode sturges, persentasi hasil simulasi menunjukkan $74 \%$ nilai median, 54\% nilai $\mathrm{Q}_{1}, 64 \%$ nilai $\mathrm{Q}_{3}, 100 \%$ nilai varians dan $98 \%$ nilai standar deviasi lebih akurat dibandingkan dengan metode sturges. Hanya pada nilai rata-rata $62 \%$ lebih akurat menggunakan metode sturges dibandingkan metode scott.

Tabel 1: Perbandingan Selisih Nilai Rata-Rata dan Nilai Median dari Data Normal

\begin{tabular}{ccccccc}
\hline Ukuran & \multicolumn{2}{c}{ Rata-Rata } & \multicolumn{2}{c}{ Keterangan } & Median & Keterangan \\
Sampel & Sturges & Scott & Lebih Baik & Sturges & Scott & Lebih Baik \\
\hline 20 & 0,4315 & 1,5327 & Sturges & 0,4614 & 1,1583 & Sturges \\
25 & 0,3203 & 0,3710 & Sturges & 0,0095 & 0,5645 & Sturges \\
30 & 0,4227 & 0,3133 & Scott & 0,2516 & 0,3083 & Sturges \\
35 & 0,0374 & 0,0504 & Sturges & 0,0326 & 0,1440 & Sturges \\
\hline
\end{tabular}


Wanda Maya Sari / SS Conference Series 01 (2018), Page 001-009

\begin{tabular}{|c|c|c|c|c|c|c|}
\hline 40 & 0,0471 & 0,2697 & Sturges & 0,7503 & 1,0614 & Sturges \\
\hline 45 & 0,2992 & 0,0403 & Scott & 0,2504 & 0,1470 & Scott \\
\hline 50 & 0,3614 & 0,1284 & Scott & 0,5692 & 0,4433 & Scott \\
\hline 55 & 0,0137 & 0,1104 & Sturges & 0,1259 & 0,0189 & Scott \\
\hline 60 & 0,2406 & 0,1898 & Scott & 0,9653 & 0,9672 & Sturges \\
\hline 65 & 0,2033 & 0,3770 & Sturges & 0,2366 & 0,0530 & Scott \\
\hline 70 & 0,2887 & 0,2328 & Scott & 0,7150 & 0,1625 & Scott \\
\hline 75 & 0,1850 & 0,1755 & Scott & 0,1617 & 0,0323 & Scott \\
\hline 80 & 0,2438 & 0,0721 & Scott & 0,5532 & 0,3951 & Scott \\
\hline 85 & 0,1918 & 0,1010 & Scott & 0,1080 & 0,2488 & Sturges \\
\hline 90 & 0,2052 & 0,2054 & Sturges & 0,1127 & 0,3789 & Sturges \\
\hline 95 & 0,0092 & 0,0776 & Sturges & 0,2088 & 0,0142 & Scott \\
\hline 100 & 0,2242 & 0,0351 & Scott & 0,1578 & 0,1324 & Scott \\
\hline 105 & 0,3457 & 0,0338 & Scott & 0,5833 & 0,1382 & Scott \\
\hline 110 & 0,0953 & 0,0709 & Scott & 0,0477 & 0,3062 & Sturges \\
\hline 115 & 0,1362 & 0,0228 & Scott & 0,0959 & 0,2220 & Sturges \\
\hline 120 & 0,1081 & 0,0119 & Scott & 0,1762 & 0,1085 & Scott \\
\hline 125 & 0,1063 & 0,1302 & Sturges & 0,2285 & 0,3605 & Sturges \\
\hline 130 & 0,0633 & 0,0623 & Scott & 0,0159 & 0,1448 & Sturges \\
\hline 135 & 0,1698 & 0,2560 & Sturges & 0,1563 & 0,2742 & Sturges \\
\hline 140 & 0,1103 & 0,0252 & Scott & 0,3038 & 0,2521 & Scott \\
\hline 145 & 0,1635 & 0,1689 & Sturges & 0,0227 & 0,3105 & Sturges \\
\hline 150 & 0,1520 & 0,0439 & Scott & 0,2386 & 0,0238 & Scott \\
\hline 155 & 0,0502 & 0,0916 & Sturges & 0,0228 & 0,1279 & Sturges \\
\hline 160 & 0,1409 & 0,0111 & Scott & 0,0526 & 0,2832 & Sturges \\
\hline 165 & 0,1705 & 0,0669 & Scott & 0,2663 & 0,2634 & Scott \\
\hline 170 & 0,1270 & 0,0252 & Scott & 0,2853 & 0,0701 & Scott \\
\hline 175 & 0,0105 & 0,0696 & Sturges & 0,0855 & 0,2846 & Sturges \\
\hline 180 & 0,0255 & 0,0456 & Sturges & 0,5645 & 0,2918 & Scott \\
\hline 185 & 0,0874 & 0,1061 & Sturges & 0,2663 & 0,1269 & Scott \\
\hline 190 & 0,0478 & 0,0889 & Sturges & 0,0897 & 0,0957 & Sturges \\
\hline 195 & 0,0229 & 0,0147 & Scott & 0,0422 & 0,1010 & Sturges \\
\hline 200 & 0,1162 & 0,0941 & Scott & 0,0361 & 0,0359 & Scott \\
\hline 205 & 0,1790 & 0,0730 & Scott & 0,0603 & 0,2571 & Sturges \\
\hline 210 & 0,1040 & 0,1103 & Sturges & 0,0878 & 0,1355 & Sturges \\
\hline 215 & 0,0102 & 0,0241 & Sturges & 0,0094 & 0,0189 & Sturges \\
\hline 220 & 0,0922 & 0,0891 & Scott & 0,1074 & 0,2271 & Sturges \\
\hline 225 & 0,1194 & 0,0035 & Scott & 0,0301 & 0,0657 & Sturges \\
\hline 230 & 0,0631 & 0,1721 & Sturges & 0,0547 & 0,0614 & Sturges \\
\hline 235 & 0,0152 & 0,0904 & Sturges & 0,2105 & 0,2537 & Sturges \\
\hline 240 & 0,0605 & 0,0123 & Scott & 0,0427 & 0,0034 & Scott \\
\hline 245 & 0,1811 & 0,0530 & Scott & 0,0159 & 0,0248 & Sturges \\
\hline 250 & 0,0042 & 0,0010 & Scott & 0,0764 & 0,0622 & Scott \\
\hline 255 & 0,0559 & 0,0295 & Scott & 0,0392 & 0,0089 & Scott \\
\hline 260 & 0,0044 & 0,1461 & Sturges & 0,0667 & 0,0928 & Sturges \\
\hline 265 & 0,0724 & 0,0710 & Scott & 0,1224 & 0,2648 & Sturges \\
\hline
\end{tabular}


Tabel 2: Perbandingan Selisih Nilai $Q_{1}$ dan Nilai $Q_{3}$ dari Data Normal

\begin{tabular}{|c|c|c|c|c|c|c|}
\hline \multirow{2}{*}{$\begin{array}{l}\text { Ukuran } \\
\text { Sampel }\end{array}$} & \multicolumn{2}{|c|}{$\mathrm{Q}_{1}$} & \multirow{2}{*}{$\begin{array}{l}\text { Keterangan } \\
\text { Lebih Baik }\end{array}$} & \multicolumn{2}{|c|}{$\mathrm{Q}_{3}$} & \multirow{2}{*}{$\begin{array}{l}\text { Keterangan } \\
\text { Lebih Baik }\end{array}$} \\
\hline & Sturges & Scott & & Sturges & Scott & \\
\hline 20 & 0,0306 & 1,6846 & Sturges & 0,9887 & 1,0290 & Sturges \\
\hline 25 & 0,2028 & 0,0539 & Scott & 1,6858 & 1,7686 & Sturges \\
\hline 30 & 0,7585 & 0,0227 & Scott & 1,0285 & 0,0095 & Scott \\
\hline 35 & 0,1256 & 0,0736 & Scott & 0,3198 & 0,3113 & Scott \\
\hline 40 & 0,4763 & 0,1324 & Scott & 0,2876 & 0,1910 & Scott \\
\hline 45 & 0,2051 & 0,0209 & Scott & 0,6902 & 0,3170 & Scott \\
\hline 50 & 0,6016 & 0,1264 & Scott & 0,2269 & 0,3269 & Sturges \\
\hline 55 & 0,2260 & 0,3951 & Sturges & 0,1254 & 0,0054 & Scott \\
\hline 60 & 0,0132 & 0,2828 & Sturges & 0,1600 & 0,0857 & Scott \\
\hline 65 & 0,2265 & 0,1292 & Scott & 1,3346 & 0,0862 & Scott \\
\hline 70 & 0,5916 & 0,0067 & Scott & 0,0027 & 0,4633 & Sturges \\
\hline 75 & 0,0188 & 0,1248 & Sturges & 0,2697 & 0,7672 & Sturges \\
\hline 80 & 0,5334 & 0,0242 & Scott & 0,3943 & 0,3988 & Sturges \\
\hline 85 & 0,4372 & 0,3784 & Scott & 0,0279 & 0,0942 & Sturges \\
\hline 90 & 0,2210 & 0,0057 & Scott & 0,3138 & 0,2469 & Scott \\
\hline 95 & 0,1004 & 0,4668 & Sturges & 0,0153 & 0,1641 & Sturges \\
\hline 100 & 0,1781 & 0,1646 & Scott & 0,1860 & 0,1333 & Scott \\
\hline 105 & 0,2799 & 0,1408 & Scott & 0,2883 & 0,0346 & Scott \\
\hline 110 & 0,0081 & 0,0302 & Sturges & 0,1727 & 0,1108 & Scott \\
\hline 115 & 0,0042 & 0,4582 & Sturges & 0,1435 & 0,6158 & Sturges \\
\hline 120 & 0,0265 & 0,4029 & Sturges & 0,0529 & 0,4279 & Sturges \\
\hline 125 & 0,0831 & 0,1554 & Sturges & 0,2243 & 0,3204 & Sturges \\
\hline 130 & 0,1309 & 0,2254 & Sturges & 0,0295 & 0,0015 & Scott \\
\hline 135 & 0,2095 & 0,4144 & Sturges & 0,4179 & 0,1853 & Scott \\
\hline 140 & 0,1159 & 0,1355 & Sturges & 0,0641 & 0,1954 & Sturges \\
\hline 145 & 0,1461 & 0,2670 & Sturges & 0,1750 & 0,2101 & Sturges \\
\hline 150 & 0,1738 & 0,1221 & Scott & 0,1621 & 0,2781 & Sturges \\
\hline 155 & 0,3549 & 0,2418 & Scott & 0,0378 & 0,6370 & Sturges \\
\hline 160 & 0,5268 & 0,4050 & Scott & 0,1556 & 0,1697 & Sturges \\
\hline 165 & 0,3016 & 0,0170 & Scott & 0,1517 & 0,0554 & Scott \\
\hline 170 & 0,3229 & 0,0114 & Scott & 0,2531 & 0,1226 & Scott \\
\hline 175 & 0,0357 & 0,1535 & Sturges & 2,0093 & 0,0849 & Scott \\
\hline 180 & 0,0007 & 0,3586 & Sturges & 0,4270 & 0,0249 & Scott \\
\hline 185 & 0,0786 & 0,1900 & Sturges & 0,1572 & 0,6163 & Sturges \\
\hline 190 & 0,0673 & 0,1425 & Sturges & 0,1468 & 0,0779 & Scott \\
\hline 195 & 0,0235 & 0,0465 & Sturges & 0,2615 & 0,2862 & Sturges \\
\hline 200 & 0,2566 & 0,1461 & Scott & 0,2965 & 0,1722 & Scott \\
\hline 205 & 0,2838 & 0,1571 & Scott & 0,4092 & 0,5205 & Sturges \\
\hline 210 & 0,1570 & 1,1527 & Sturges & 0,1265 & 0,0414 & Scott \\
\hline 215 & 0,0002 & 0,0218 & Sturges & 0,1072 & 0,0232 & Scott \\
\hline 220 & 0,4739 & 0,1213 & Scott & 0,2943 & 0,3749 & Sturges \\
\hline 225 & 0,2427 & 0,0967 & Scott & 0,0078 & 0,0697 & Sturges \\
\hline 230 & 0,3679 & 0,1021 & Scott & 0,1132 & 0,0496 & Scott \\
\hline 235 & 0,3166 & 0,1855 & Scott & 0,3059 & 0,0534 & Scott \\
\hline
\end{tabular}




\begin{tabular}{llllllc}
\hline 240 & 0,1163 & 0,0514 & Scott & 0,4079 & 0,2791 & Scott \\
245 & 0,2076 & 0,1059 & Scott & 0,0023 & 0,1191 & Sturges \\
250 & 0,0293 & 0,0145 & Scott & 0,3644 & 0,0941 & Scott \\
255 & 0,0351 & 0,0230 & Scott & 0,1432 & 0,2392 & Sturges \\
260 & 0,1755 & 0,0835 & Scott & 0,0036 & 0,0377 & Sturges \\
265 & 0,1167 & 0,2244 & Sturges & 0,3079 & 0,0164 & Scott \\
\hline
\end{tabular}

Tabel 3: Perbandingan Selisih Nilai $s^{2}$ dan Nilaisdari Data Normal

\begin{tabular}{|c|c|c|c|c|c|c|}
\hline \multirow{2}{*}{$\begin{array}{l}\text { Ukuran } \\
\text { Sampel }\end{array}$} & \multicolumn{2}{|c|}{$s^{2}$} & \multirow{2}{*}{$\begin{array}{l}\text { Keterangan } \\
\text { Lebih Baik }\end{array}$} & \multicolumn{2}{|c|}{$\mathrm{Q}$} & \multirow{2}{*}{$\begin{array}{l}\text { Keterangan } \\
\text { Lebih Baik }\end{array}$} \\
\hline & Sturges & Scott & & Sturges & Scott & \\
\hline 20 & 7,1086 & 1,2341 & Scott & 0,7469 & 0,1217 & Scott \\
\hline 25 & 0,2261 & 2,3715 & Sturges & 0,0244 & 0,2648 & Sturges \\
\hline 30 & 6,7034 & 1,8445 & Scott & 0,6758 & 0,1770 & Scott \\
\hline 35 & 2,908 & 0,1917 & Scott & 0,3571 & 0,0226 & Scott \\
\hline 40 & 2,3953 & 1,2888 & Scott & 0,2546 & 0,1316 & Scott \\
\hline 45 & 3,0642 & 0,4661 & Scott & 0,3224 & 0,0476 & Scott \\
\hline 50 & 5,3537 & 1,1112 & Scott & 0,4505 & 0,0907 & Scott \\
\hline 55 & 2,0173 & 1,1287 & Scott & 0,2328 & 0,1287 & Scott \\
\hline 60 & 2,7623 & 1,2306 & Scott & 0,3090 & 0,1350 & Scott \\
\hline 65 & 2,3792 & 0,3502 & Scott & 0,2566 & 0,0366 & Scott \\
\hline 70 & 4,3682 & 0,8986 & Scott & 0,4518 & 0,0896 & Scott \\
\hline 75 & 1,7041 & 0,8573 & Scott & 0,1594 & 0,0785 & Scott \\
\hline 80 & 2,7936 & 1,7000 & Scott & 0,2846 & 0,1655 & Scott \\
\hline 85 & 3,3657 & 0,4931 & Scott & 0,4084 & 0,0567 & Scott \\
\hline 90 & 1,8099 & 0,9036 & Scott & 0,1728 & 0,0856 & Scott \\
\hline 95 & 0,9699 & 0,1981 & Scott & 0,0942 & 0,0191 & Scott \\
\hline 100 & 1,0269 & 0,4023 & Scott & 0,1033 & 0,0402 & Scott \\
\hline 105 & 3,0713 & 0,1133 & Scott & 0,3072 & 0,0110 & Scott \\
\hline 110 & 1,7748 & 0,4346 & Scott & 0,1765 & 0,0423 & Scott \\
\hline 115 & 1,1856 & 0,1873 & Scott & 0,1159 & 0,0181 & Scott \\
\hline 120 & 1,3858 & 0,8044 & Scott & 0,1449 & 0,0822 & Scott \\
\hline 125 & 2,3845 & 0,2952 & Scott & 0,2157 & 0,0262 & Scott \\
\hline 130 & 3,1367 & 0,1571 & Scott & 0,3072 & 0,0149 & Scott \\
\hline 135 & 1,3228 & 0,0758 & Scott & 0,1389 & 0,0078 & Scott \\
\hline 140 & 2,4324 & 0,1799 & Scott & 0,2447 & 0,0177 & Scott \\
\hline 145 & 1,6566 & 1,0130 & Scott & 0,1726 & 0,1026 & Scott \\
\hline 150 & 1,1941 & 0,7325 & Scott & 0,129 & 0,0774 & Scott \\
\hline 155 & 0,4247 & 0,0569 & Scott & 0,0406 & 0,0055 & Scott \\
\hline 160 & 0,3781 & 0,4169 & Sturges & 0,0395 & 0,0436 & Sturges \\
\hline 165 & 0,3567 & 0,0876 & Scott & 0,0383 & 0,0094 & Scott \\
\hline 170 & 0,2796 & 0,2171 & Scott & 0,0256 & 0,4801 & Sturges \\
\hline 175 & 1,4250 & 0,8186 & Scott & 0,1306 & 0,0754 & Scott \\
\hline 180 & 0,6593 & 0,0795 & Scott & 0,0669 & 0,0080 & Scott \\
\hline 185 & 0,4946 & 0,5053 & Sturges & 0,0560 & 0,0565 & Sturges \\
\hline 190 & 0,0445 & 0,1466 & Sturges & 0,0046 & 0,0152 & Sturges \\
\hline 195 & 0,8824 & 0,3872 & Scott & 0,0891 & 0,0389 & Scott \\
\hline 200 & 1,0659 & 1,9690 & Sturges & 0,1071 & 0,1921 & Sturges \\
\hline 205 & 0,1604 & 0,3616 & Sturges & 0,0172 & 0,0385 & Sturges \\
\hline
\end{tabular}




\begin{tabular}{lllllll}
\hline 210 & 4,2286 & 0,0128 & Scott & 0,0315 & 0,0492 & Sturges \\
215 & 4,2043 & 0,5076 & Scott & 0,0317 & 0,0013 & Scott \\
220 & 0,5581 & 0,4734 & Scott & 0,0571 & 0,0485 & Scott \\
225 & 1,1915 & 1,0189 & Scott & 0,1092 & 0,0918 & Scott \\
230 & 0,8685 & 0,1688 & Scott & 0,0906 & 0,0174 & Scott \\
235 & 0,6737 & 0,2018 & Scott & 0,0687 & 0,0207 & Scott \\
240 & 1,2715 & 0,5777 & Scott & 0,1344 & 0,0598 & Scott \\
245 & 0,4008 & 0,0509 & Scott & 0,0382 & 0,0054 & Scott \\
250 & 0,3811 & 0,3797 & Sturges & 0,0374 & 0,0373 & Scott \\
255 & 0,9062 & 0,6121 & Scott & 0,0870 & 0,0589 & Scott \\
260 & 0,4415 & 0,0871 & Scott & 0,0452 & 0,0089 & Scott \\
265 & 0,9140 & 0,5796 & Scott & 0,0919 & 0,0575 & Scott \\
\hline
\end{tabular}

Pada percobaan simulasi dengan ukuran sampel 200 sampai 445, didapatkan perbandingan keakuratan tabel distribusi frekuensi dengan metode scott lebih akurat dari metode sturges. Untuk data normal, persentasi perbandingannya adalah $70 \%$ nilai rata-rata, $56 \%$ nilai median, $64 \%$ nilai $\square_{1}, 52 \%$ nilai $\square_{3}, 86 \%$ nilai $s$, dan $86 \%$ nilai $s^{2}$. Untuk data eksponensial, persentasi perbandingannya adalah $66 \%$ nilai rata-rata, $52 \%$ nilai median, $86 \%$ nilai $\square_{1}, 60 \%$ nilai $\square_{3}$, $100 \%$ nilai $s$, dan $100 \%$ nilai $s^{2}$. Hasil perbandingan menunjukkan keakuratan yang lebih tinggi dibandingkan percobaan simulasi dengan ukuran sampel 20 sampai 265.

\section{Kesimpulan}

Dari hasil persentase perbandingan keakuratan antara model tabel distribusi frekuensi menggunakan metode sturges dan metode scott, dapat diambil kesimpulan bahwa keakuratan model scott lebih baik dari model sturges pada data normal, dan terjadi peningkatan persentase keakuratan pada data eksponensial. Pada percobaan simulasi dengan ukuran sampel yang lebih tinggi yaitu ukuran sampel 200 sampai 445, terjadi pula peningkatan persentase keakuratan, dengan model scott tetap lebih baik dari model sturges. Pada penelitian ini, nilai pengukuran dari model sturges kurang akurat dibandingkan dengan model scott, dikarenakan adanya data yang tidak masuk dalam tabel distribusi frekuensi, diakibatkan nilai panjang kelas interval tidak mencakup pengelompokkan sampai data tertinggi.

\section{Referensi}

[1] Sturges, H. (1926). The Choice of A Class Interval. Journal American Statistical Association. 21.65-66

[2] Dajan, A.nto. (1986). Pengantar Metode Statistik 2. LP3ES. Jakarta.

[3] Hyndman, Rob J. (1995). The Problem with Sturges's Rule for Constructing Histograms. A shortnotes. Unpublished Article.

[4] Scott, David W. (1979). On Optimal Data-Based Histograms. Biometrika Trust. 3.605-610 